\title{
Appraisal of seasonal variation of groundwater quality near an uncontrolled municipal solid waste landfill in Kolkata, India
}

\author{
De S.*, Maiti S.K., Hazra T., Debsarkar A. and Dutta A. \\ Department of Civil Engineering, Jadavpur University, Kolkata 700032, India \\ Received: 06/11/2016, Accepted: 28/12/2016, Available online: 06/10/2017 \\ *to whom all correspondence should be addressed: \\ e-mail: sde@research.jdvu.ac.in, shushmitaa2010@gmail.com
}

\begin{abstract}
The present study was aimed to evaluate the impact of leachate derived from uncontrolled municipal landfill on surrounding groundwater quality in Kolkata, India. Seasonal variation of twenty physico-chemical parameters in pre-monsoon (PRM) and post-monsoon (POM) season were analysed in forty groundwater samples around the landfill site. Groundwater pollution was identified by the spatial distribution maps of TDS, $\mathrm{Na}^{+}, \mathrm{Cl}^{-}, \mathrm{Mn}$ and Fe along with the heavy metals like $\mathrm{Pb}, \mathrm{Hg}$ and $\mathrm{Cr}$ in both the seasons. Hydrogeochemical characteristics of groundwater samples showed that the area was dominated by brackish water, $\left[\mathrm{Ca}^{+2}-\mathrm{Cl}^{-}\right],\left[\mathrm{Mg}^{+2}-\mathrm{Cl}^{-}\right]$and $\left[\mathrm{Na}^{+}-\mathrm{Cl}^{-}\right]$type in PRM season whereas $\left[\mathrm{Na}^{+}-\mathrm{HCO}_{3}{ }^{-}\right]$type dominated in POM season. Hierarchical cluster analysis (HCA) was also applied to identify the source of groundwater pollution. In PRM season, groundwater samples closer to the active landfill site were physico-chemically different from upstream samples but more related to downstream samples. However, in POM season, groundwater samples closer to the active landfill site represented distinctly different physico-chemical characteristics from upstream and downstream samples as a result of high influx of leachate pollutants. In specific, the present study urges for proper pollution control measures along with landfill leachate treatment process to improve the surrounding water quality.
\end{abstract}

Keywords: Uncontrolled municipal landfill, Leachate, Groundwater quality, Hydrogeochemical characteristics, Hierarchical cluster analysis (HCA)

\section{Introduction}

Population growth and urbanization tends to produce high volumes of solid waste from different sources of urban society. However, lack of adequate regulatory system for proper solid waste management could result in serious ecological, environmental and health complications. Sanitary landfilling of municipal solid waste (MSW) is the most conventional management measure practiced in most of the developed countries. However, in developing countries like India, open dumping is prevalent for disposing solid wastes. In most of the cases, MSW are directly disposed in open or uncontrolled landfills without any or little regard towards the geo-membrane liners, leachate collection systems and treatment facilities (De et al., 2016). However, generation of leachate is inevitable for both the sanitary or open/uncontrolled landfills. Landfill leachates are produced as a result of rainfall percolation along with chemical, physico-chemical and microbiological processes occurring within the disposed waste mass (Li et al., 2010). Leachates are the potential source of various pollutants like dissolved organic matter, inorganic macrocomponents, heavy metals and xenobiotic organic compounds (Christensen et al., 1994). In India, Ministry of Environment, Forests and Climate Change (MoEFCC), has notified MSW landfill leachate discharge standards to protect the receiving waters in 2000 and amended them in 2016. As a consequence of open or uncontrolled landfilling, leachates accumulate at the base of the landfill site and percolate through the soil or flow out laterally to contaminate surrounding soil, groundwater and surface water resources (Matejczyk et al., 2011). In India, several instances of groundwater pollution pertaining to uncontrolled landfilling have been reported in near past (Mor et al., 2006; Kale et al., 2010; Parameswari et al., 2012). The majority of India's population depends on groundwater for drinking and on surface water for agricultural activities and pisciculture. Thus, water pollution not only leads to deterioration of water quality but also threatens human health. Henceforth, protection of water resources is essential to maintain social well-being and economic growth of any nation.

Until now in Kolkata, a metropolitan city of India, groundwater pollution problems related to municipal landfills have not been yet studied. Hence, assessment of groundwater quality around the uncontrolled landfill site in Kolkata is an emergency to protect the local people of the landfill site. Thus, in the present study, the objectives were to (1) assess the landfill hazard by examining leachate characteristics; (2) investigate the seasonal variation of groundwater quality evaluating the influence of landfill leachate and suitability for drinking and irrigational purposes; (3) assess the spatial distribution of physicochemical parameters delineating the extent of groundwater pollution; (4) identify the source of 
groundwater pollutants through hydrogeochemical and clustering analysis.

\section{Materials and Methods}

\subsection{Study area}

The present study was undertaken at Dhapa uncontrolled landfill site located in the extreme east of Kolkata city, India (Figure 1).

The study area lies between latitude $22^{\circ} 30^{\prime} 24.47^{\prime \prime}$ to $22^{\circ}$ $32^{\prime} 54.57^{\prime \prime} \mathrm{N}$ and longitude $88^{\circ} 24^{\prime} 13.76^{\prime \prime}$ to $88^{\circ} 27^{\prime} 43.96^{\prime \prime}$
E within East Kolkata Wetlands (EKW). The wetland comprises of intertidal marshes, ponds and shallow water bodies locally known as "jheels" and "bheries" which are used for agricultural farming and pisciculture respectively. EKW covers an area of about 10,000 ha of which Dhapa landfill site involves a portion of 24.71 ha (Hazra and Goel, 2009) with an alluvial soil type of moderate permeability $10^{-5}$ to $10^{-6} \mathrm{~cm} \mathrm{~s}^{-1}$. About $60 \%$ of the wetland surrounding the landfill site comprises of a low-income neighborhood of rag pickers, jheels, bheries and agricultural lands.

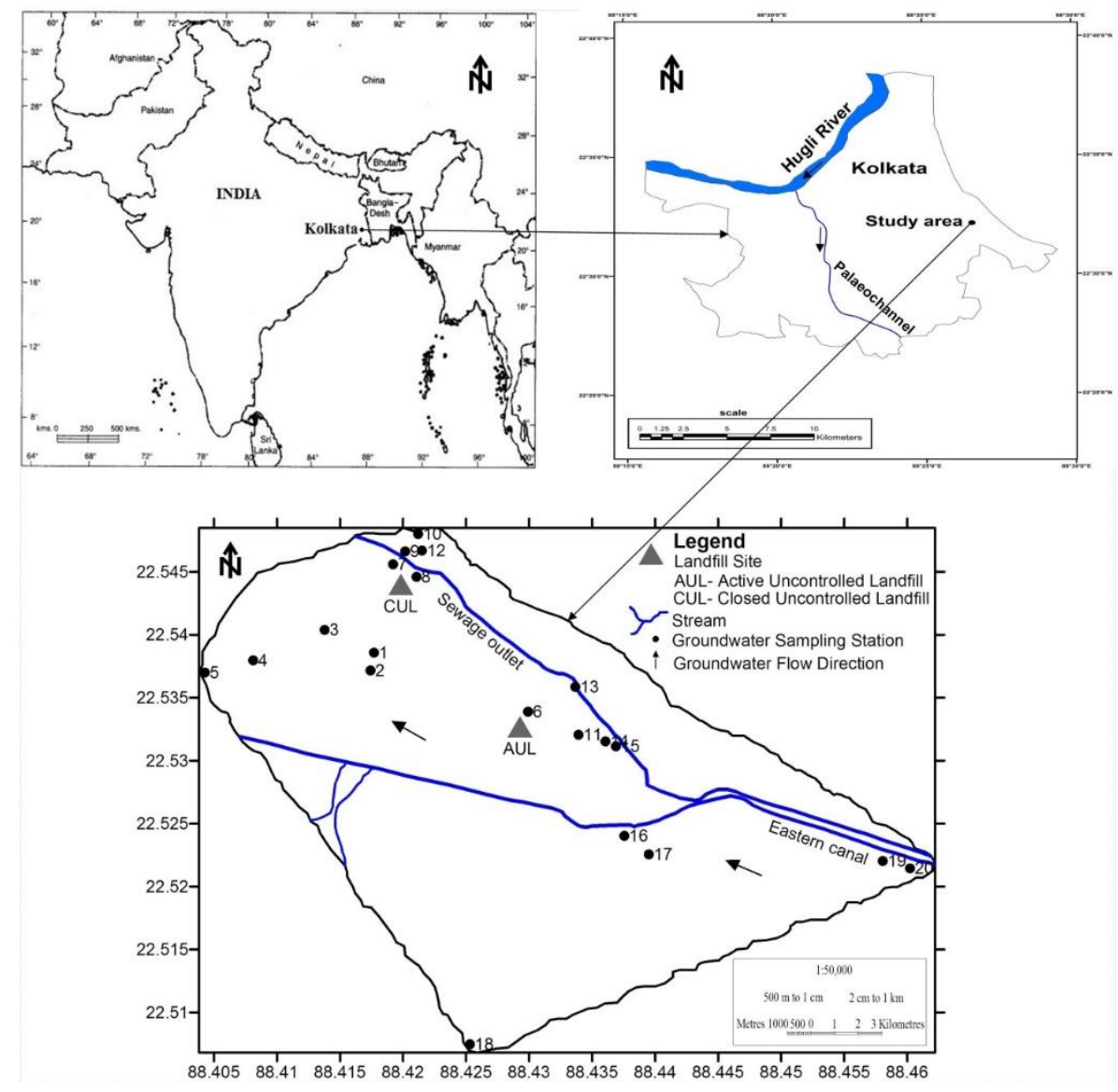

Figure 1. Location of the study area showing sampling stations around the Dhapa landfill site

The landfill site receives around 3000 tons of MSW per day from Kolkata city since 1981(Chattopadhyay et al., 2009) and devoid of any kind of groundwater protection measures and leachate collection system. Kolkata belongs to hot and humid climatic regime with the temperature varying between $12^{\circ} \mathrm{C}$ to $40^{\circ} \mathrm{C}$. Relative humidity generally ranges between $68 \%$ in March to $85 \%$ in August with an annual average rainfall of $1650 \mathrm{~mm}$ receiving from northeast and southwest monsoons. Groundwater and surface water are also used to get their supply from monsoon season which generally extend from June to October. The depth of the water table in the study area is approximately $14 \mathrm{~m}$ below ground level (mbgl) in premonsoon (PRM) season and $12 \mathrm{mbgl}$ in post-monsoon (POM) season. A high level of groundwater table persists in and around the study area as a consequence of percolation from the surrounding water bodies. There is also a groundwater trough near the western Kolkata (Sahu and
Sikdar, 2008). Thus, in the study area groundwater flows from east to west in direction (Sahu and Sikdar, 2008) and can transport pollutants from the landfill site located in the EKW towards the aquifer system of the central and western Kolkata.

\subsection{Sampling and analysis}

The topographical map (79B/6) of Kolkata of scale 1:50,000 was procured from the Survey of India (SOI) to delineate the boundary of the study area. The locations of the landfill site and groundwater sampling stations were attributed as shown in Figure1.

Composite leachate samples were regularly collected every month (12 sampling periods from January to December) from the base of the waste dump. Composite samples were obtained by manually mixing spot leachate samples from spatially distributed sources to yield representative leachate samples. A total of forty $(20 \times 2)$ groundwater 
water samples were collected from wells within an area of $3.5 \mathrm{~km}$ from the landfill site for two different seasons, PRM and POM during April 2014 and November 2014 respectively. Leachate and groundwater samples were kept in pre acid-washed polyethylene bottles at $4{ }^{\circ} \mathrm{C}$ for further laboratory analysis. $100 \mathrm{ml}$ of the collected samples were filtered using $0.45 \mu \mathrm{m}$ Millipore membrane filter papers and were acidified with $5 \mathrm{~N}$ nitric acid to $\mathrm{pH}<2$ and kept on $4{ }^{\circ} \mathrm{C}$ for the determination of the heavy metals. All the analytical reagents and chemical standards used were of Merck, analytical grade (AR) and the selected parameters were subsequently analyzed in triplicate. The analytical methods were according to the internationally accepted procedures and standard (APHA AWWA WPCF, 1999) to determine $\mathrm{pH}, \mathrm{EC}, \mathrm{TDS}, \mathrm{Ca}^{+2}, \mathrm{Mg}^{+2}, \mathrm{Na}^{+}, \mathrm{K}^{+}, \mathrm{F}^{-}, \mathrm{Cl}^{-}$, $\mathrm{HCO}_{3}{ }^{-}, \mathrm{SO}_{4}{ }^{2-}, \mathrm{PO}_{4}{ }^{-}, \mathrm{NO}_{3}{ }^{-}, \mathrm{NH}_{3}-\mathrm{N}, \mathrm{TKN}, \mathrm{COD}$ and $\mathrm{BOD}_{5}$. Dissolved heavy metals like $\mathrm{As}, \mathrm{Cd}, \mathrm{Cr}, \mathrm{Cu}, \mathrm{Fe}, \mathrm{Hg}, \mathrm{Mn}, \mathrm{Ni}$, $\mathrm{Pb}$ and $\mathrm{Zn}$ were detected by atomic absorption spectrometry (Perkin Elmer AAnalyst 400) equipped with graphite furnace (HGA Graphite Furnace).

The geospatial data of the sampling stations were recorded by using a Garmin GPS system and the spatial distribution maps for selected parameters of groundwater samples were prepared by kriging interpolation technique using Surfer version 8 software.

Sodium adsorption ratio (SAR), residual sodium carbonate (RSC) and sodium percentage ( $\mathrm{Na} \%$ ) were also determined for groundwater samples.

Salinity laboratory of the US Department of Agriculture has recommended SAR for analyzing irrigational water quality (Wilcox 1955) which can be calculated by the following formula (where the ions are in $\mathrm{meq} / \mathrm{L}$ )

$$
\mathrm{SAR}=\frac{\mathrm{Na}^{+}}{\sqrt{\frac{\mathrm{Ca}^{+2}+\mathrm{Mg}^{+2}}{2}}}
$$

RSC can be calculated using the following formula (where the ions are in $\mathrm{meq} / \mathrm{L}$ )

$$
\mathrm{RSC}=\left[\left(\mathrm{HCO}_{3}^{-}+\mathrm{CO}_{3}^{2-}\right)-\left(\mathrm{Ca}^{+2}+\mathrm{Mg}^{+2}\right)\right]
$$

$\mathrm{Na} \%$ can be evaluated by the formula given below (where the ions are in $\mathrm{meq} / \mathrm{L}$ )

$$
\mathrm{Na} \%=\frac{\left(\mathrm{Na}^{+}+\mathrm{K}^{+}\right) \times 100}{\mathrm{Ca}^{+2}+\mathrm{Mg}^{+2}+\mathrm{Na}^{+}+\mathrm{K}^{+}}
$$

\subsection{Hydrogeochemical classification of groundwater}

The hydrogeochemical classification of the groundwater samples was determined by plotting the concentrations of anions and cations on the Piper trilinear diagram (Piper, 1944). The dominant anion and cation in each groundwater sample can be identified from the right and left ternary diagrams respectively. $\left[\mathrm{SO}_{4}{ }^{2-}\right],\left[\mathrm{HCO}_{3}{ }^{-}\right]$and $\left[\mathrm{Cl}^{-}\right]$are the anionic constituents of the right ternary diagram while $\left[\mathrm{Ca}^{+2}\right],\left[\mathrm{Mg}^{+2}\right]$, and $\left[\mathrm{Na}^{+}\right]$are the cationic constituents of the left ternary diagram. The hydrogeochemical characteristics of the groundwater sample can be determined by combining the predominant ions at each sampling station (Nguyen et al., 2014).

\subsection{Hierarchical Cluster Analysis (HCA)}

HCA was applied to identify the source of groundwater pollutants in PRM and POM seasons by using Statistical Package for Social Sciences (SPSS) version 20. In the present study, the interval of Euclidean distance was used for clustering the groundwater samples and the clustering method of ward linkage was applied to associate the clusters. To achieve the cluster analysis normal distribution and homogeneity of the variances were assumed and the data were standardized to their corresponding $\mathrm{z}$ scores (Yidana et al., 2010). In HCA, standardization of data is crucial as Euclidean distance is largely influenced by the high variances of the data (Li et al., 2012). For the computation of HCA, the data of the parameters were represented with detection limit values when the concentrations were found below the detection limit of the applied technique.

\section{Results and Discussion}

\subsection{Leachate characterisation}

Table 1 summarizes the leachate analysis results and were compared with the leachate discharge standards for inland surface water as specified by MoEFCC (2016).

Dhapa landfill site was in the methanogenic phase as the leachate was characterized by alkaline $\mathrm{pH}(8.2)$, low value of COD (4933.50 $\mathrm{mg} \mathrm{L}^{-1}$ ), intermediate $\mathrm{BOD}_{5} / \mathrm{COD}$ ratio (0.47) and high value of $\mathrm{NH}_{3}-\mathrm{N}\left(1596.57 \mathrm{mg} \mathrm{L}^{-1}\right)$. BOD $5 / C O D$ ratio of 0.47 indicated that the landfill leachate is at the intermediate level of biodegradability as the process of waste deposition still continues in the landfill site. However, acidogenic leachate was not observed due to the presence of high bicarbonate concentration (29317.44 $\mathrm{mg} \mathrm{L}^{-1}$ ) along with the high ratio of the old disposed waste to the newly deposited waste (Demirbilek et al., 2013). Landfill leachate under study may act as a potential source of groundwater pollution due to the presence of high values of TDS ( $9007.50 \mathrm{mg} \mathrm{L}^{-1}$ ) along with the conservative pollutants like $\mathrm{Cl}^{-}\left(3973.11 \mathrm{mg} \mathrm{L}^{-1}\right), \mathrm{Na}^{+}\left(2267.91 \mathrm{mg} \mathrm{L}^{-1}\right)$ and $\mathrm{K}^{+}\left(1688.19 \mathrm{mg} \mathrm{L}^{-1}\right)$. High concentrations of $\mathrm{NH}_{3}-\mathrm{N}$ indicate the occurence of reducing environment in leachate which leads to high levels of soluble Fe $(3.89 \mathrm{mg}$ $\mathrm{L}^{-1}$ ) and $\mathrm{Mn}$ (1.89 $\left.\mathrm{mg} \mathrm{L}^{-1}\right)$. Methanogenic leachates are usually associated with low concentrations of heavy metals (Kjeldsen et al., 2002) due to the sorption and precipitation reactions with sulphides, carbonates and hydroxides (Lo, 1996). However, in the current study, some of the heavy metals like $\mathrm{Cr}\left(2.54 \mathrm{mg} \mathrm{L}^{-1}\right), \mathrm{Hg}\left(0.98 \mathrm{mg} \mathrm{L}^{-1}\right), \mathrm{Pb}(0.63 \mathrm{mg}$ $\left.\mathrm{L}^{-1}\right)$ and $\mathrm{Zn}\left(6.16 \mathrm{mg} \mathrm{L}^{-1}\right)$ were present in high concentrations exceeding the permissible discharge limits. Maiti et al. (2016) also reported similar trend of heavy metal contamination from the Dhapa landfill site, Kolkata. This may be due to the insufficient or low-availability of the sorption and precipitation reactants. 


\subsection{Groundwater quality for drinking}

Table 2 depicts the statistical summary of groundwater analysis results for PRM and POM seasons. The suitability of groundwater samples for drinking purposes was analysed by comparing with WHO (1971, 1993, 2002, 2004, and 2011) drinking water quality standards.

Table 1. Leachate characteristics of the Dhapa uncontrolled landfill site in Kolkata, India

\begin{tabular}{|c|c|c|c|c|}
\hline Parameters $^{\mathrm{a}}$ & Mean $\pm S D^{b}$ & Range & $\begin{array}{c}\text { No. of } \\
\text { samples }\end{array}$ & $\frac{\text { Leachate discharge standards }}{\text { Inland surface water }}$ \\
\hline $\mathrm{pH}$ & $8.20 \pm 0.17$ & $7.8-8.6$ & 12 & $5.5-9$ \\
\hline $\mathrm{EC}$ & $27364.88 \pm 11960$ & $9557.14-52600$ & 12 & - \\
\hline TDS & $9007.50 \pm 3571$ & $2320-15700$ & 12 & 2100 \\
\hline $\mathrm{Na}^{+}$ & $2267.91 \pm 1375$ & $292.11-5342$ & 12 & - \\
\hline $\mathrm{K}^{+}$ & $1688.19 \pm 996$ & $168.37-3375$ & 12 & - \\
\hline $\mathrm{F}^{-}$ & $1.06 \pm 1.11$ & $0.20-2.53$ & 12 & 2 \\
\hline $\mathrm{Cl}^{-}$ & $3973.11 \pm 1446$ & $2103-6735$ & 12 & 1000 \\
\hline $\mathrm{HCO}_{3}^{-}$ & $29317.44 \pm 29357$ & $5319.20-127032$ & 12 & - \\
\hline $\mathrm{SO}_{4}{ }^{2-}$ & $1721.20 \pm 1670$ & $52.50-5730$ & 12 & - \\
\hline $\mathrm{PO}_{4}{ }^{3-}$ & $33.27 \pm 45.72$ & $1.20-156$ & 12 & - \\
\hline $\mathrm{NO}_{3}^{-}$ & $28.50 \pm 13.30$ & $9.45-59.20$ & 12 & - \\
\hline $\mathrm{NH}_{4}^{+}$ & $1596.57 \pm 1288$ & $168-4210$ & 12 & 50 \\
\hline TKN & $4455.93 \pm 3214$ & $631-9139$ & 12 & 100 \\
\hline COD & $4933.50 \pm 3189$ & $1200-13200$ & 12 & 250 \\
\hline $\mathrm{BOD}_{5}$ & $2317.00 \pm 1702$ & $525-6440$ & 12 & 30 \\
\hline As & $0.10 \pm 0.19$ & $0.0045-0.5610$ & 12 & 0.2 \\
\hline $\mathrm{Cd}$ & $0.66 \pm 0.94$ & $0.006-2.11$ & 12 & 2.0 \\
\hline $\mathrm{Cr}$ & $2.54 \pm 3.25$ & $0.104-10.43$ & 12 & 2.0 \\
\hline $\mathrm{Cu}$ & $0.30 \pm 0.14$ & $0.14-0.68$ & 12 & 3.0 \\
\hline $\mathrm{Fe}$ & $3.89 \pm 3.52$ & $0.80-11.25$ & 12 & - \\
\hline $\mathrm{Hg}$ & $0.98 \pm 0.99$ & $0.16-2.65$ & 12 & 0.01 \\
\hline $\mathrm{Mn}$ & $1.89 \pm 0.91$ & $0.68-3.90$ & 12 & - \\
\hline $\mathrm{Ni}$ & $0.48 \pm 0.20$ & $0.20-0.77$ & 12 & 3.0 \\
\hline $\mathrm{Pb}$ & $0.63 \pm 0.25$ & $0.37-1.14$ & 12 & 0.1 \\
\hline $\mathrm{Zn}$ & $6.16 \pm 6.66$ & $1-25.14$ & 12 & 5.0 \\
\hline
\end{tabular}

aAll concentrations are given in $\mathrm{mg} \mathrm{L}^{-1}$ except $\mathrm{pH}$ and EC $(\mu \mathrm{S} / \mathrm{cm})$, bStandard deviation, ${ }^{\mathrm{c} M o E F C C ~} 2016$

Table 2. Physico-chemical parameters and heavy metal content for groundwater around Dhapa uncontrolled landfill, Kolkata, India in PRM and POM season

\begin{tabular}{|c|c|c|c|c|c|c|}
\hline \multirow[t]{2}{*}{ Parameters $^{a}$} & \multicolumn{2}{|c|}{ PRM } & \multicolumn{2}{|c|}{ POM } & \multicolumn{2}{|c|}{ WHO standard } \\
\hline & Mean $\pm S D^{b}$ & Range & Mean $\pm S D^{b}$ & Range & $\begin{array}{c}\text { Desirable } \\
\text { limit }\end{array}$ & $\begin{array}{c}\text { Permissible } \\
\text { limit }\end{array}$ \\
\hline $\mathrm{pH}$ & $7.30 \pm 0.14$ & $7.1-7.6$ & $7.20 \pm 0.26$ & $7-7.8$ & $7-8.5$ & 9.2 \\
\hline TDS & $1148.00 \pm 295$ & $711-1820$ & $1045.00 \pm 742$ & $400-3390$ & 500 & 1500 \\
\hline $\mathrm{Ca}^{+2}$ & $147.47 \pm 45$ & $24.02-248.25$ & $147.84 \pm 67$ & $26.02-320.32$ & 75 & 200 \\
\hline $\mathrm{Mg}^{+2}$ & $80.71 \pm 16$ & $51.94-120.48$ & $95.19 \pm 66$ & $41.20-328.01$ & 50 & 150 \\
\hline $\mathrm{Na}^{+}$ & $139.32 \pm 48$ & $85.23-281.91$ & $287.14 \pm 127$ & $173.91-739.13$ & - & 200 \\
\hline $\mathrm{K}^{+}$ & $2.46 \pm 0.83$ & $1.27-3.92$ & $3.44 \pm 0.81$ & $1.47-5.16$ & - & 12 \\
\hline $\mathrm{Cl}^{-}$ & $435.26 \pm 135$ & $156.55-715.83$ & $480.86 \pm 263$ & $141.80-1264.09$ & 200 & 600 \\
\hline $\mathrm{HCO}_{3}^{-}$ & $376.78 \pm 67$ & $259.25-535.75$ & $1449.94 \pm 456$ & $881.45-2825.83$ & - & 500 \\
\hline $\mathrm{SO}_{4}{ }^{2-}$ & $21.18 \pm 13$ & $12-65.75$ & $22.99 \pm 11$ & $4.15-51.55$ & 200 & 400 \\
\hline $\mathrm{NO}_{3}^{-}$ & $1.7 \pm 0.42$ & $0.71-2.38$ & $1.3 \pm 0.81$ & $0.54-4.38$ & - & 50 \\
\hline As & $0.0031 \pm 0.003$ & $B D L^{c}-0.009$ & $0.0036 \pm 0.003$ & $\mathrm{BDL}^{\mathrm{c}}-0.0088$ & - & 0.01 \\
\hline $\mathrm{Cd}$ & $0.01 \pm 0.0019$ & $0.0097-0.017$ & $0.02 \pm 0.001$ & $0.016-0.022$ & - & 0.003 \\
\hline $\mathrm{Cr}$ & $0.04 \pm 0.03$ & $\mathrm{BDL}^{\mathrm{d}}-0.08$ & $0.05 \pm 0.02$ & $0.03-0.14$ & - & 0.05 \\
\hline $\mathrm{Cu}$ & $0.0047 \pm 0.001$ & $0.0029-0.0079$ & $0.0060 \pm 0.002$ & $0.0028-0.0094$ & - & 2.0 \\
\hline $\mathrm{Fe}$ & $0.53 \pm 0.39$ & $0.02-1.73$ & $2.29 \pm 2.19$ & $0.067-9.57$ & - & 0.3 \\
\hline $\mathrm{Hg}$ & $0.22 \pm 0.1$ & $0.02-0.36$ & $0.23 \pm 0.05$ & $0.15-0.3$ & - & 0.006 \\
\hline $\mathrm{Mn}$ & $0.30 \pm 0.08$ & $0.15-0.45$ & $0.26 \pm 0.09$ & $0.09-0.47$ & - & 0.5 \\
\hline $\mathrm{Ni}$ & $0.04 \pm 0.02$ & $0.01-0.08$ & $0.02 \pm 0.01$ & $0.0076-0.05$ & - & 0.07 \\
\hline $\mathrm{Pb}$ & $0.02 \pm 0.01$ & $0.005-0.05$ & $0.06 \pm 0.05$ & $0.008-0.2$ & - & 0.01 \\
\hline $\mathrm{Zn}$ & $1.29 \pm 0.51$ & $0.42-2.11$ & $0.22 \pm 0.13$ & $0.0056-0.54$ & - & 5.0 \\
\hline
\end{tabular}

${ }^{a}$ All concentrations are given in $\mathrm{mg} \mathrm{L}^{-1}$ except $\mathrm{pH}$, ${ }^{\mathrm{b}}$ Standard deviation, ${ }^{\mathrm{c} B D L}-$ Below Detection Limit of $0.0002 \mathrm{mg} \mathrm{L}^{-1},{ }^{\mathrm{d} B D L}-\mathrm{Below}$ Detection Limit of $0.00003 \mathrm{mg} \mathrm{L}^{-1}$ 


\subsubsection{Physico-chemical characteristics of groundwater}

The $\mathrm{pH}$ of all groundwater samples was neutral and within the desirable limits of WHO standards during PRM and POM seasons respectively. TDS of majority of groundwater samples exceeded the WHO desirable limit of $500 \mathrm{mg} \mathrm{L}^{-1}$ indicating its unsuitability for drinking purposes. Higher TDS values were observed in both the seasons in GW6, GW11, GW14 and GW15 which were in the close vicinity of the active landfill site indicating the presence of leachate contamination (Fig. 2). Similar trend of TDS was also observed by Mor et al. (2006). These high values of TDS may be due to the leaching of various inorganic pollutants into the ground water. The results showed a gradual decrease in TDS concentration in both the seasons as the distance of groundwater samples increases from the active landfill site attributing to the effect of leachate infiltration in the nearby groundwater (Fig. 3a and $a^{\prime}$ ).
PRM Season

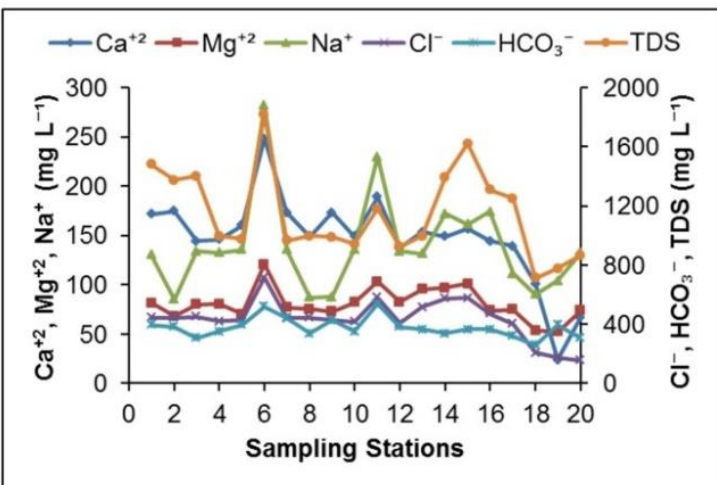

POM Season

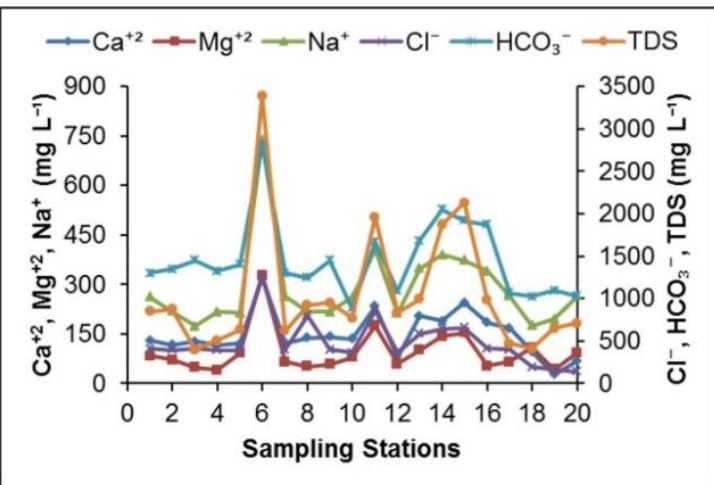

Figure 2. Seasonal variation of physico-chemical parameters in groundwater samples
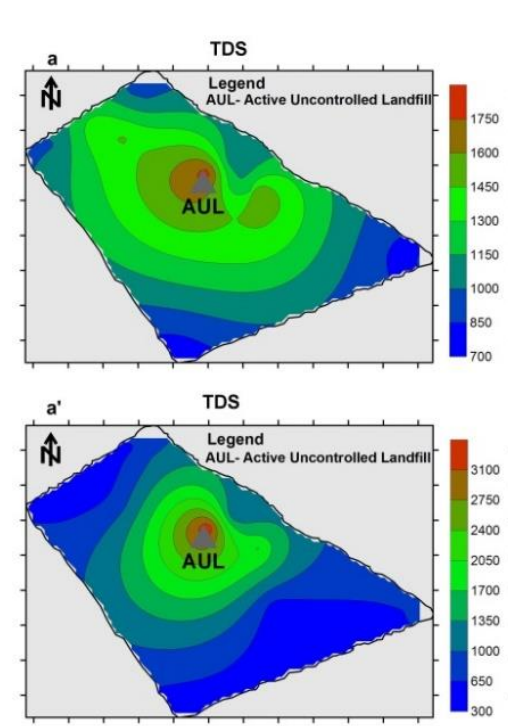

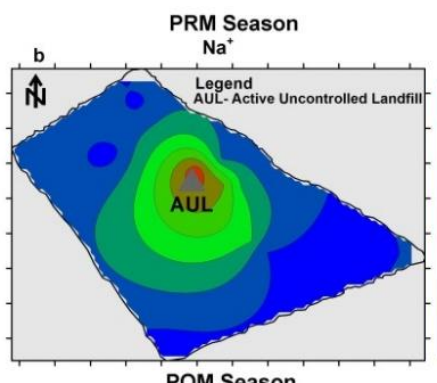

POM Season

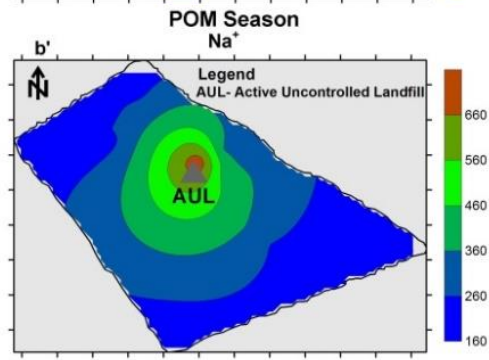

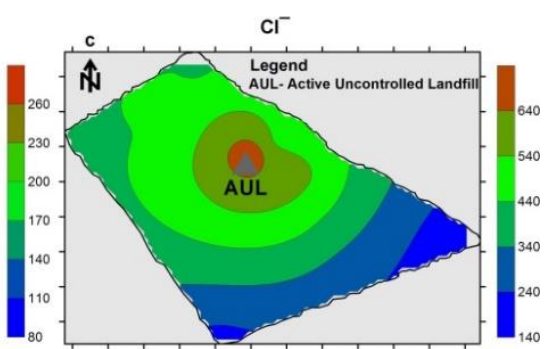

$\mathrm{Cl}^{-}$

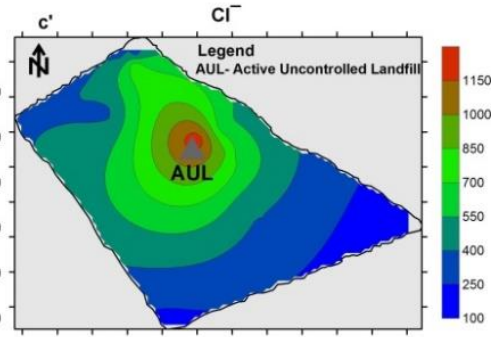

Figure 3. Spatial distribution maps of TDS, $\mathrm{Na}^{+}$and $\mathrm{Cl}^{-}$of groundwater samples (Concentrations are in $\mathrm{mg} \mathrm{L}^{-1}$ )

In the PRM season, $\mathrm{Ca}^{+2}$ and $\mathrm{Mg}^{+2}$ concentrations were found to be higher than the WHO desirable limits in $90 \%$ and $100 \%$ of groundwater samples respectively. In terms of meq $\mathrm{L}^{-1}$, percentage of $\mathrm{Ca}^{+2}, \mathrm{Mg}^{+2}, \mathrm{Na}^{+}$and $\mathrm{K}^{+}$ions in PRM season were $36.96,32.28,30.44$ and 0.32 respectively. Thus the decreasing hierarchy of major cations was $\mathrm{Ca}^{+2}$ $>\mathrm{Mg}^{+2}>\mathrm{Na}^{+}>\mathrm{K}^{+}$in PRM season. Whereas, in the POM season, $\mathrm{Ca}^{+2}$ concentrations were found to surpass the WHO desirable limit in $90 \%$ of groundwater samples whereas $\mathrm{Mg}^{+2}$ and $\mathrm{Na}^{+}$were above the WHO limit in $85 \%$ of samples. In terms of meq $\mathrm{L}^{-1}$, percentage of $\mathrm{Ca}^{+2}, \mathrm{Mg}^{+2}$, $\mathrm{Na}^{+}$and $\mathrm{K}^{+}$ions in POM season were 26.55, 28.18, 44.95 and 0.32 respectively. Thus the decreasing hierarchy of major cations was $\mathrm{Na}^{+}>\mathrm{Mg}^{+2}>\mathrm{Ca}^{+2}>\mathrm{K}^{+}$in $\mathrm{POM}$ season.
The concentrations and hierarchy of cations changed as a result of seasonal effect with leachate percolation in groundwater. Likewise in the PRM season, $\mathrm{Cl}^{-}$was present in higher concentrations in $90 \%$ of groundwater samples exceeding the WHO desirable limit for drinking. In terms of meq $\mathrm{L}^{-1}$, percentage of $\mathrm{Cl}^{-}, \mathrm{HCO}_{3}{ }^{-}, \mathrm{SO}_{4}{ }^{2-}$ and $\mathrm{NO}_{3}{ }^{-}$ions in PRM season were $64.89,32.64,2.33$ and 0.14 respectively. Thus the decreasing hierarchy of major anions was $\mathrm{Cl}^{-}>$ $\mathrm{HCO}_{3}{ }^{-}>\mathrm{SO}_{4}{ }^{2-}>\mathrm{NO}_{3}{ }^{-}$in PRM season. But in the POM season, $\mathrm{Cl}^{-}$and $\mathrm{HCO}_{3}{ }^{-}$concentrations were found to be higher than the WHO prescribed limit in $90 \%$ and $100 \%$ of groundwater samples respectively. In terms of meq $\mathrm{L}^{-1}$, percentage of $\mathrm{Cl}^{-}, \mathrm{HCO}_{3}{ }^{-}, \mathrm{SO}_{4}{ }^{2-}$ and $\mathrm{NO}_{3}{ }^{-}$ions in POM season were $35.86,62.82,1.27$ and 0.06 respectively. Thus 
the decreasing hierarchy of major anions was $\mathrm{HCO}_{3}{ }^{-}>\mathrm{Cl}^{-}>$ $\mathrm{SO}_{4}{ }^{2-}>\mathrm{NO}_{3}{ }^{-}$in POM season. Seasonal effect also changed the concentrations of anions indicating the recharge of groundwater along with the admixing of landfill leachate within the aquifer matrix. Higher concentrations of $\mathrm{Ca}^{+2}$, $\mathrm{Mg}^{+2}, \mathrm{Na}^{+}, \mathrm{Cl}^{-}$and $\mathrm{HCO}_{3}{ }^{-}$were found in GW6, GW11, GW13, GW14 and GW15 which were closest to the active landfill site (Fig. 2). Moreover, in both the seasons, $\mathrm{Na}^{+}$and $\mathrm{Cl}^{-}$, the characteristic pollutants of landfill leachate represented a gradual decrease in concentration in groundwater samples as the distance increases from the active landfill site implicating the influence of leachate on groundwater (Fig. 3b, b', c and $c^{\prime}$ ). Thus, in this study, the presence of high concentrations of TDS, $\mathrm{Ca}^{+2}, \mathrm{Mg}^{+2}, \mathrm{Na}^{+}$, $\mathrm{Cl}^{-}$and $\mathrm{HCO}_{3}{ }^{-}$ions can be attributed to the landfill leachate as the concentration of these elements were much higher than their natural background values in Kolkata (Supplementary Table 1) (WBPCB, 2014).

Supplementary Table 1. Natural background values of physico-chemical parameters of groundwater of Kolkata in 2014

\begin{tabular}{cccc}
\hline Parameters $^{\mathrm{a}}$ & Min & Max & Mean \\
\hline $\mathrm{pH}$ & 7.50 & 7.80 & 614.67 \\
$\mathrm{TDS}$ & 494 & 694 & 85.33 \\
$\mathrm{Ca}^{+2}$ & 72.00 & 104.00 & 38.07 \\
$\mathrm{Mg}^{+2}$ & 19.44 & 53.46 & 123.80 \\
$\mathrm{Na}^{+}$ & 72.90 & 154.30 & 3.67 \\
$\mathrm{~K}^{+}$ & 3.00 & 5.00 & 121.48 \\
$\mathrm{Cl}^{-}$ & 107.63 & 136.98 & 300.00 \\
$\mathrm{HCO}_{3}^{-}$ & 190.00 & 370.00 & 14.19 \\
$\mathrm{SO}_{4}^{2-}$ & $\mathrm{BDL}$ & 29 & 0.26 \\
$\mathrm{NO}^{-}$ & 0.01 & 0.55 & $\mathrm{BDL}$ \\
$\mathrm{As}$ & - & - & $\mathrm{BDL}$ \\
$\mathrm{Cd}$ & - & - & 0.0027 \\
$\mathrm{Total} \mathrm{Cr}$ & $\mathrm{BDL}$ & 0.0063 & $\mathrm{BDL}$ \\
$\mathrm{Cu}$ & - & - & 0.32 \\
$\mathrm{Fe}$ & 0.10 & 0.45 & 0.00085 \\
$\mathrm{Hg}$ & $\mathrm{BDL}$ & 0.0013 & $\mathrm{BDL}$ \\
$\mathrm{Ni}$ & - & - & $\mathrm{BDL}$ \\
$\mathrm{Pb}$ & - & - & 0.37 \\
\hline
\end{tabular}

aAll concentrations are given in $\mathrm{mg} \mathrm{L}^{-1}$ except $\mathrm{pH}$, ${ }^{\mathrm{b}} \mathrm{BDL}-$ Below Detection Limit, Source: WBPCB, 2014

\section{PRM Season}

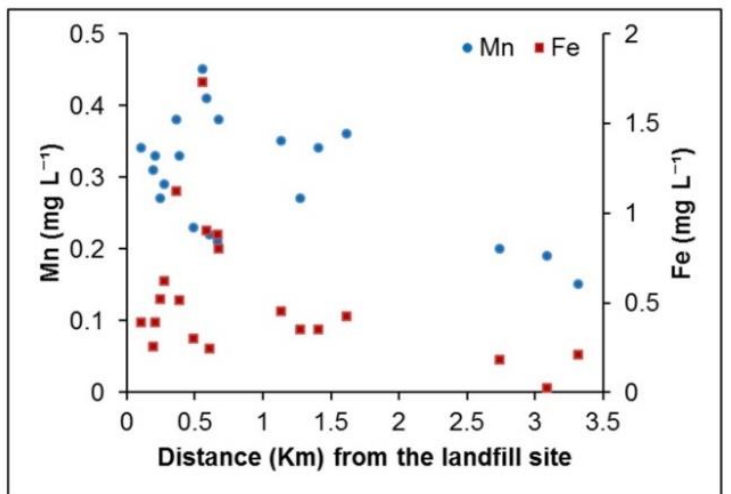

POM Season

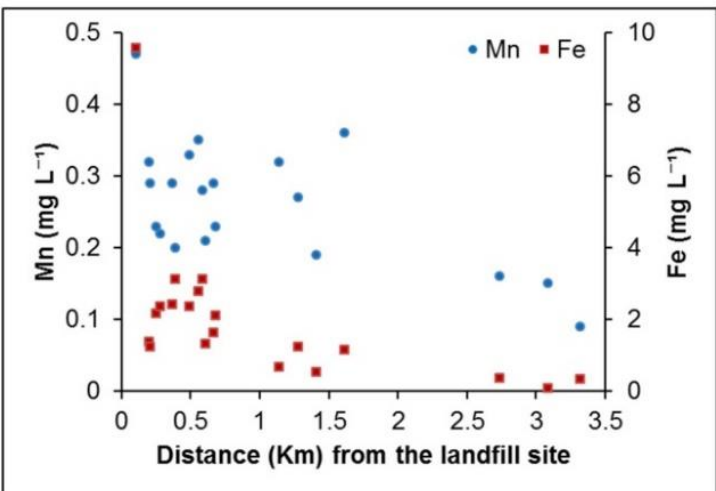

Figure 4. Spatial variation of $\mathrm{Mn}$ and Fe with increasing distance from the landfill site

\subsection{2. $\mathrm{Mn}$ and $\mathrm{Fe}$}

Landfill leachate is a reducing effluent which solubilizes the adsorbed $\mathrm{Mn}$ and Fe after infiltrating into the groundwater aquifer (Mor et al., 2006). Although Mn concentration of all groundwater samples was within the WHO permissible limit in both the seasons, Fe concentration exceeded the WHO permissible limit in $70 \%$ and $90 \%$ of groundwater samples in PRM and POM season respectively. High concentration of $\mathrm{Fe}$ was also reported in groundwater surrounding landfill site of erode city, Tamil Nadu, India (Nagarajan et al., 2012). However, Mn and Fe sourced from landfill leachate can be identified as $\mathrm{Mn}$ and Fe values in groundwater samples gradually decreases as the distance increases from the active landfill site (Fig. 4). The lower values of $\mathrm{Mn}$ and $\mathrm{Fe}$ at the distant sampling stations from the landfill site indicated the prevalence of oxidizing condition as $\mathrm{Mn}$ and Fe precipitates in the range of neutral $\mathrm{pH}$ under oxidizing environment.

\subsubsection{Heavy metals}

Leachate plume of Dhapa landfill site showed relatively high concentrations of heavy metals. Thus groundwater in the studied area was highly contaminated with heavy metals like $\mathrm{Cd}, \mathrm{Cr}, \mathrm{Hg}, \mathrm{Ni}$ and $\mathrm{Pb}$ in both the seasons as a result of very little effect of redox control on the heavy 
metal transport. However, the concentrations of $\mathrm{As}, \mathrm{Cu}$ and $\mathrm{Zn}$ in both the seasons were within the WHO stipulated standard in all the sampling stations. $\mathrm{Pb}, \mathrm{Hg}$ and $\mathrm{Cd}$ in both the seasons were detected above the WHO permissible limit in all the sampling stations (Table 2). $\mathrm{Pb}$ and $\mathrm{Hg}$ showed a declining trend in concentration as the distance of sampling stations increases from the active landfill site implicating the direct mixing of leachate in groundwater (Fig. 5a, a', b and ' b'). However, $\mathrm{Pb}$ was also high at remote sampling stations like GW19 and GW20 upstream to the active landfill site may be due to some geogenic sources. In
PRM season, Cd with highest concentration was found at GW18 (0.017 $\left.\mathrm{mg} \mathrm{L}^{-1}\right)$ away from active landfill site and in POM season, GW16 (0.022 $\left.\mathrm{mg} \mathrm{L}^{-1}\right)$ showed highest concentration which indicated some local anthropogenic activities. During PRM and POM season, $\mathrm{Cr}$ was found to be higher than the WHO permissible limit in 35\% and $70 \%$ of groundwater samples respectively. $\mathrm{Cr}$ showed the highest concentration in GW6 closest to the active landfill site and its concentration gradually decreases from the active landfill (Fig. 5c and $c^{\prime}$ ).
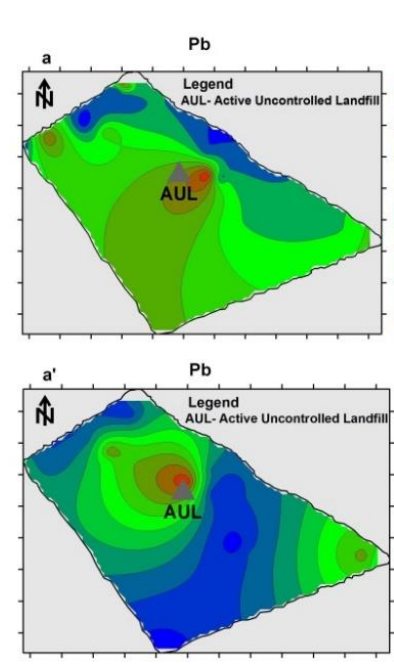

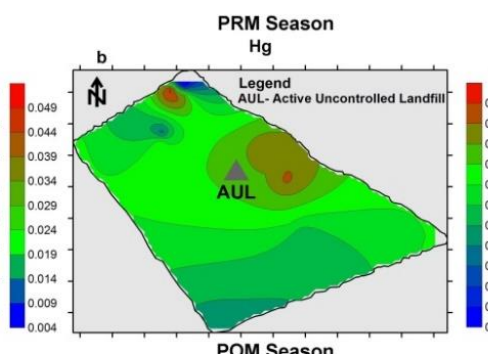

POM Season
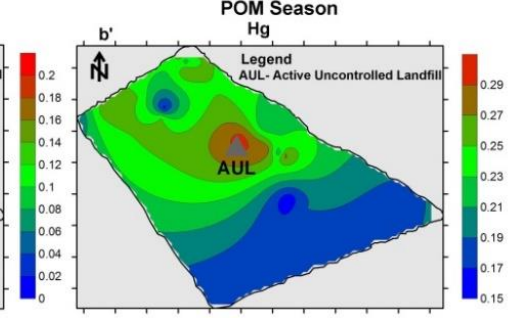
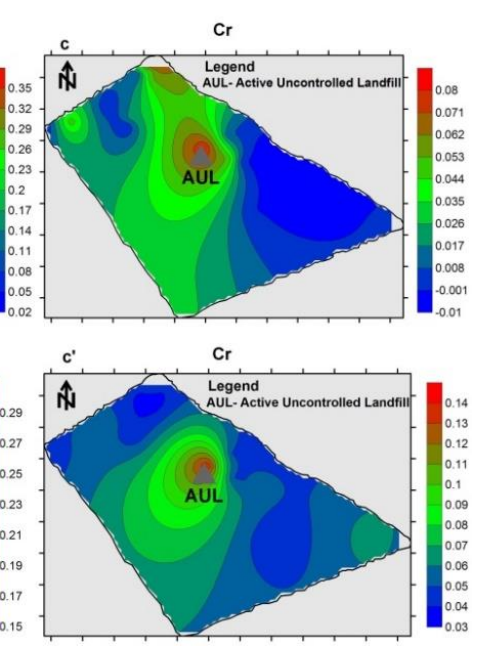

Figure 5. Spatial distribution maps of $\mathrm{Pb}, \mathrm{Hg}$ and $\mathrm{Cr}$ of groundwater samples (Concentrations are in $\mathrm{mg} \mathrm{L}^{-1}$ )

In PRM season high values of Ni were present in GW6 $(0.07$ $\left.\mathrm{mg} \mathrm{L}^{-1}\right)$, GW11 (0.08 $\left.\mathrm{mg} \mathrm{L}^{-1}\right)$ and GW14 $\left(0.07 \mathrm{mg} \mathrm{L}^{-1}\right)$. Apart from these sampling stations, $\mathrm{Ni}$ in both the seasons was below the stipulated standards. Generally, attenuation processes like sorption and precipitation delimit the extent of heavy metal pollution in groundwater surrounding landfills. However in this study, heavy metals in leachate significantly affected the groundwater despite cation exchange capacity of the soil column and attenuation mechanisms. These high values of heavy metals can be attributed to the deficient or unavailable sorption and precipitation reactants within the aquifer matrix. Similarly, like the major ions, the high concentration of $\mathrm{Cd}, \mathrm{Cr}, \mathrm{Hg}, \mathrm{Ni}$ and $\mathrm{Pb}$ in the study area can be imputed to the landfill leachate as the concentration of these elements were much higher than their natural background values in Kolkata (Supplementary Table 1) (WBPCB, 2014).

\subsection{Groundwater suitability for Irrigation}

Groundwater analysis results of the study area based on SAR, RSC and Na\% were also determined to compare with irrigational water quality standards in PRM and POM seasons.

\subsubsection{Sodium Adsorption Ratio (SAR)}

SAR is one of the important parameters to assess irrigational water quality as it signifies alkali or sodium hazard to vegetation (Ramesh and Elango, 2012). SAR varied from 1.39 to 3.67 in PRM season and 2.89 to 6.94 in POM season which indicated that all groundwater samples were suitable for irrigational purposes. Irrigation water causes permeability hazards when SAR values are more than 10. In both the season, GW6 closest to the active landfill site showed the highest SAR value implicating the mixing of landfill leachate into the groundwater. Moreover, all groundwater samples exhibited higher SAR values in POM season in comparison to PRM season as a result of dissolution of $\mathrm{Na}^{+}$with the leachate flowing out from the landfill site.

\subsubsection{Residual Sodium Carbonate}

Suitability as irrigation water can also be identified by evaluating RSC (Siddiqui et al., 2005). According to USEPA (1999), irrigation waters are safe when RSC $<1.25$ and becomes unsuitable as RSC exceeds 2.5. RSC in groundwater ranged from -13.78 to 1.05 meq $L^{-1}$ in PRM season and 1.29 to 17.14 meq $\mathrm{L}^{-1}$ in POM season. Negative $\mathrm{RSC}$ indicated that excess concentrations of $\mathrm{Ca}^{+2}$ and $\mathrm{Mg}^{+2}$ were present in PRM season. Thus on the basis of RSC, groundwater samples in PRM season were suitable for irrigation. However, in POM season, $85 \%$ of samples exceeded the RSC limit implying the dissolution of landfill leachate in groundwater.

\subsubsection{Sodium Percentage}

Percentage of sodium ( $\mathrm{Na} \%$ ) is another vital parameter to assess suitability of irrigation water (Wilcox 1948). Water samples for irrigation is suitable when $\mathrm{Na} \%<35$ meq $\mathrm{L}^{-1}$ (Vasanthavigar et al., 2010). Na\% in groundwater varied between 20.99 to 45.97 meq L ${ }^{-1}$ in PRM season and 35.75 
to 64.11 meq $\mathrm{L}^{-1}$ in POM season. In PRM season, $10 \%$ of samples (GW6 and GW11) closest to the active landfill site showed Na\% exceeding $35 \mathrm{meq} / \mathrm{L}$. However, in POM season, all of the groundwater samples exhibited higher $\mathrm{Na} \%$ making it unsuitable for irrigation. These higher values can be attributed to the mixing of pollutants from leachate and also may be due to the intrusion of chemical fertilizers from the nearby agricultural fields.

\subsection{Hydrogeochemical classification of groundwater}

The hydrogeochemical characteristics of the groundwater samples in the studied area were observed through the Piper trilinear diagrams. Distribution of water types in the Quaternary aquifer underlying the study area shows that the aquifer has 4 water types during PRM season and 2 water types during POM season (Fig. 6). $90 \%$ of groundwater samples collected during PRM season were characterized as brackish type (65\% as $\left[\mathrm{Ca}^{+2}-\mathrm{Cl}^{-}\right]$type, $15 \%$ $\left[\mathrm{Mg}^{+2}-\mathrm{Cl}^{-}\right]$and $10 \%\left[\mathrm{Na}^{+}-\mathrm{Cl}^{-}\right]$type), which can be

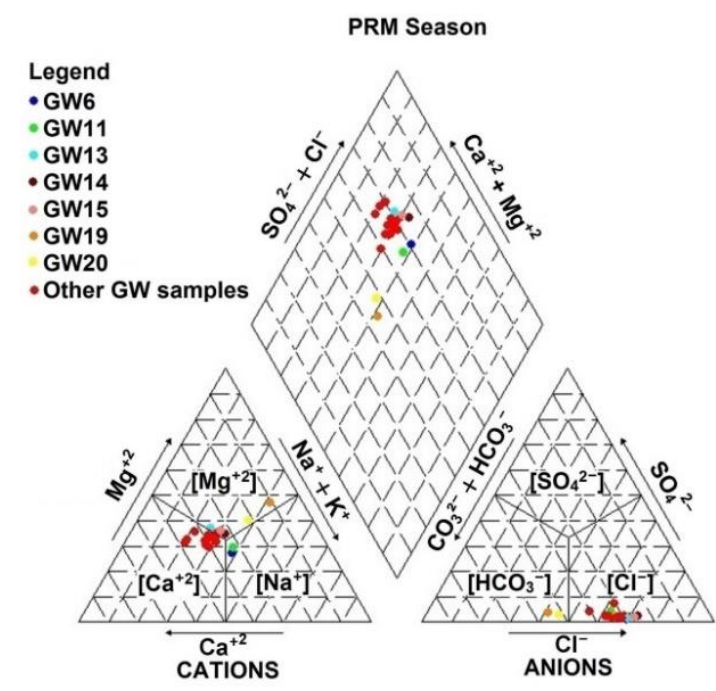

attributed to the intrusion of landfill leachate into the groundwater as $\mathrm{Cl}^{-}$is one of the major characteristic pollutant of landfill leachate. $\left[\mathrm{Na}^{+}-\mathrm{Cl}^{-}\right]$type characteristic of saline water was found in GW6 and GW11, closest to the active landfill site clearly showing the input of $\mathrm{Na}^{+}$and $\mathrm{Cl}^{-}$ ions from landfill leachate. Rest $10 \%$ of groundwater samples (GW19 and GW20) upstream to active landfill site were characterized as $\left[\mathrm{Mg}^{+2}-\mathrm{HCO}_{3}{ }^{-}\right]$type which represents background water quality of the study area. During POM season, $95 \%$ of groundwater samples were identified as $\left[\mathrm{Na}^{+}-\mathrm{HCO}_{3}{ }^{-}\right]$type and $5 \%$ as $\left[\mathrm{Mg}^{+2}-\mathrm{HCO}_{3}{ }^{-}\right]$type. $\left[\mathrm{Na}^{+}-\mathrm{HCO}_{3}{ }^{-}\right]$type was observed may be as a result of aquifer recharge along with the cation exchange with $\mathrm{Ca}^{+2}$ implying the mixing of $\mathrm{Na}^{+}$from landfill leachate. GW18 far away from active landfill site showed $\left[\mathrm{Mg}^{+2}-\mathrm{HCO}_{3}{ }^{-}\right]$type. But GW19 and GW20 showed $\left[\mathrm{Na}^{+}-\mathrm{HCO}_{3}{ }^{-}\right]$type which can be attributed to the agricultural return flow as the area is highly used for cultivation.

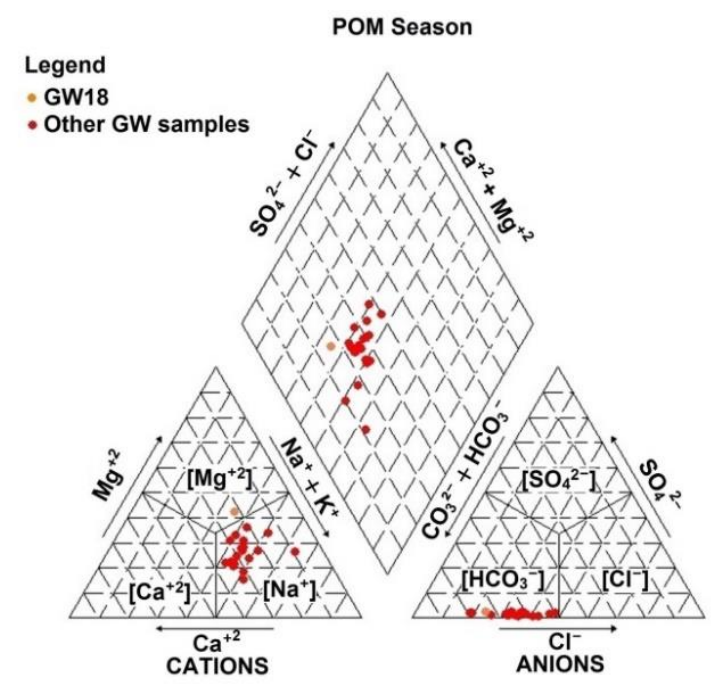

Figure 6. Piper diagram for groundwater samples in PRM and POM season

\subsection{Hierarchical Cluster Analysis (HCA)}

In order to better understand the sources of groundwater pollutants, HCA was performed on the groundwater samples in PRM and POM seasons for clustering the physico-chemically similar groundwater samples. In PRM season, 6 clusters named C1-C 6 were identified by drawing an imaginary phenon line across the dendogram at a linkage distance of 10 (Fig. 7).

More or less number of clusters could be specified by sliding the phenon line through the dendogram to obtain significant clusters of samples (Li et al., 2012). C1 linked to other clusters at the highest linkage distance indicating lowest similarity among C1 with other clusters. Groundwater samples of C1 (GW16, GW18, GW19 and GW20) were distinctly different from other clusters since C1 samples were comparatively unpolluted as located upstream to the active landfill site. C2 (GW6 and GW11) represented the highly polluted groundwater samples which were closest to the active landfill site and linked to C3-C4 and C5-C6 at a lower linkage distance indicating groundwater samples of C2 were physico-chemically similar to C3-C4 and C5-C6. C3 and C4 along with C5 and C6 are linked to each other at the lowest linkage distance indicating higher similarity among them. C3 (GW13, GW14 and GW15) represented the groundwater samples closer to the active landfill site whereas C4 (GW1, GW2, GW3 and GW8) represented the groundwater samples closer to the closed landfill site. Since the rate of dispersion of leachate pollutants was restricted in PRM season, C3 and C4 showed higher degree of similarity. C5 (GW4, GW9, GW10 and GW12) and C6 (GW5 and GW7) showed similarity as these groundwater samples were located downstream to the active landfill site.

In POM season, 3 clusters named C1-C3 were identified by drawing phenon line across the dendogram at a linkage distance of about 8 (Fig. 7). C1 (GW6, GW11, GW13, GW14 and GW15) represented the highly polluted groundwater samples which were closer to the active landfill site. Within C1, GW6 was linked to other samples at a higher linkage distance as GW6 (closest to the active landfill site) was most polluted indicating the high infiltration of landfill leachate in groundwater. C2 (GW16, GW18, GW19 and 
GW20) and C3 (GW1, GW2, GW3, GW4, GW5, GW7, GW8, GW9, GW10 and GW12) represented the groundwater samples which were located upstream and downstream to the active landfill site respectively. C1 linked to C2-C3 at a higher linkage distance representing $\mathrm{C} 1$ samples as physico-chemically different from other clusters signifying

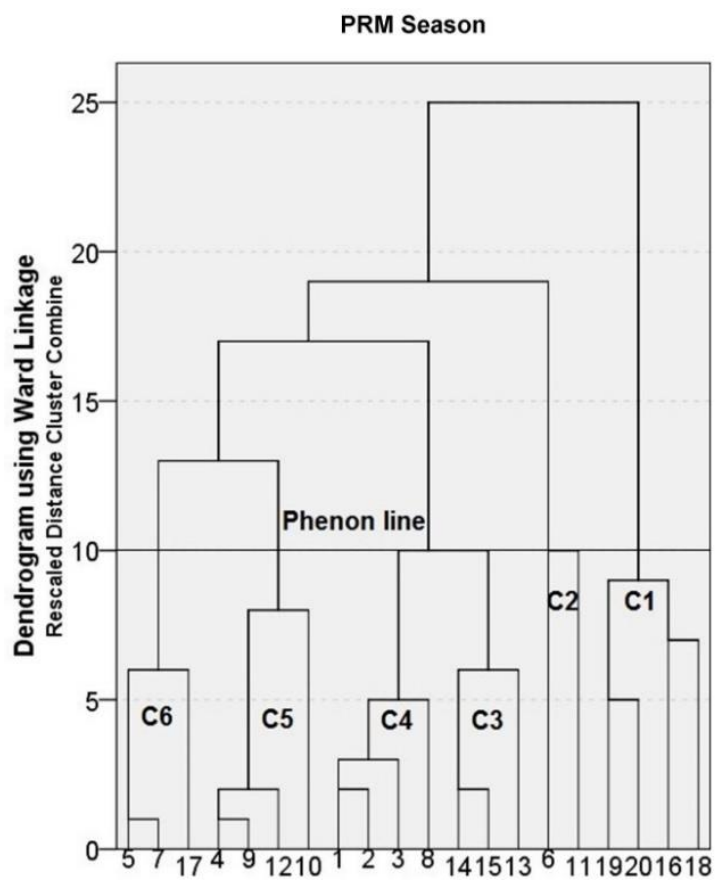

the influence of landfill leachate in nearby groundwater. GW17 which was located upstream to the active landfill site clustered in C6 in PRM season and C3 in POM season of downstream samples may be due to some geogenic sources.

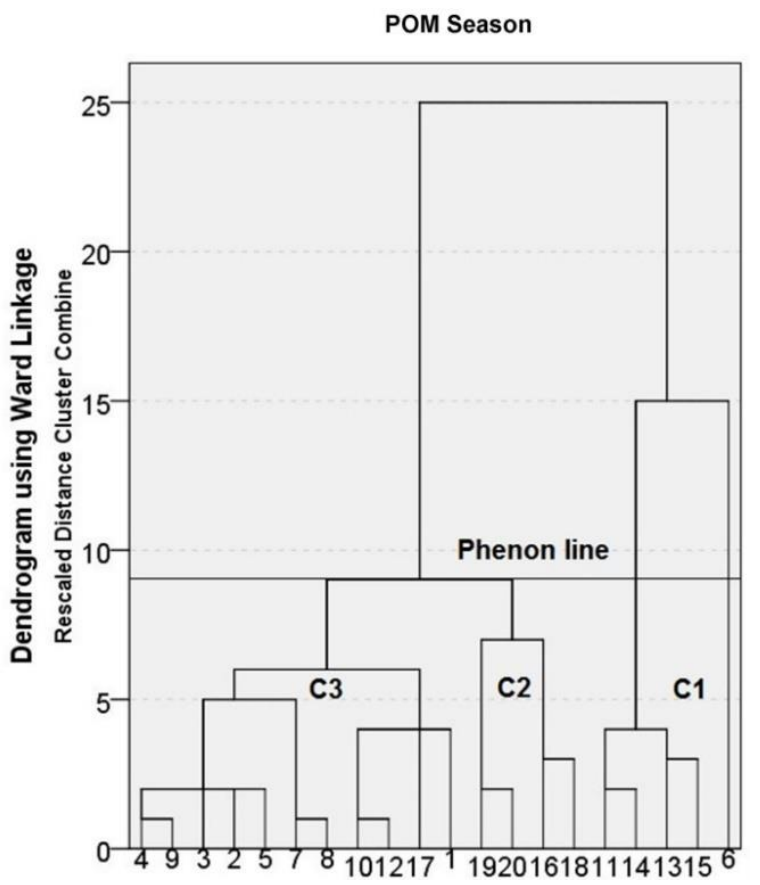

Figure 7. Dendogram for groundwater samples in PRM and POM season

\section{Conclusions}

The major environmental concern in the present study indicated the toxic effect of uncontrolled landfill leachate on the surrounding groundwater quality. The impact of leachate percolation on the surrounding groundwater was evidenced from the reducing environment along with higher concentrations of pollutants closer to the active landfill site. In terms of hydrogeochemical classification, majority of groundwater samples in PRM season were characterized as brackish $\left(\mathrm{Ca}^{+2}-\mathrm{Cl}^{-}, \mathrm{Mg}^{+2}-\mathrm{Cl}^{-}\right.$and $\mathrm{Na}^{+}-\mathrm{Cl}^{-}$ type) and specifically $\left[\mathrm{Na}^{+}-\mathrm{Cl}^{-}\right]$type was observed closest to the active landfill site as a result of landfill leachate intrusion. However in POM season, majority of the groundwater samples were characterized as $\left[\mathrm{Na}^{+}-\mathrm{HCO}_{3}{ }^{-}\right]$ type indicating the recharge of the groundwater aquifer along with the admixing of landfill leachate. Moreover, the hierarchical cluster analysis demonstrated that in PRM season, highly contaminated samples of C2 (closest to the active landfill site) were physico-chemically different from C1 (upstream samples) but more similar to other clusters (C3, C4, C5 and C6) which were located closer and downstream to the active landfill site. However in POM, highly contaminated samples of $\mathrm{C} 1$ (closest to the active landfill site) became physico-chemically distinct to C2 (upstream) and C3 (downstream) clusters as an effect of dissolution of high concentration of leachate pollutants. Moreover on the basis of WHO drinking water quality standards, groundwater in this area is not at all suitable for drinking and would be toxic to health. Nevertheless, on the basis of irrigational water quality standards, RSC and $\mathrm{Na} \%$ indicated that groundwater samples were suitable for irrigation only in PRM season. The SAR values were found to be high in POM season. Therefore, the present study indicated the need for pre-treatment process on landfill leachate before draining in to surrounding jheels and bheries. Moreover, immediate attention is required towards the continuous monitoring and remediation of the groundwater around the Dhapa landfill site to prevent further deterioration of the water quality.

\section{Acknowledgements}

One of the authors, Sushmita De, thanks University Grants Commission (UGC), New Delhi, India for granting research fellowship to conduct the present research. Authors would also like to acknowledge Kolkata Municipal Corporation (KMC) for providing the support and necessary facilities to carry out the field work.

\section{References}

APHA-AWWA-WPCF, Standard Methods for the Examination of Water and Wastewater, $20^{\text {th }} \mathrm{Eds}$ American Public Health Association, Washington, DC, USA (1999).

Chattopadhyay S., Dutta A. and Ray S. (2009), Municipal solid waste management in Kolkata, India - A review, Waste Management, 29,1449-1458.

Christensen T.H., Kjeldsen P., Albrechtsen H.J., Heron G., Nielson P.H., Bjerg P.L. and Holm P.E. (1994), Attenuation of landfill leachate pollutants in aquifers, Critıcal Reviews in Environmental Science and Technology, 24, 119-202. 
De S., Maiti S.K., Hazra T., Debsarkar A. and Dutta A. (2016), Leachate characterization and identification of dominant pollutants using leachate pollution index for an uncontrolled landfill site, Global Journal of Environmental Science and Management, 2(2), 177-186.

Demirbilek D., Onal A.O., Demir V., Uslu G. and Arslanoglu-Isik H. (2013), Characterization and pollution potential assessment of Tunceli, Turkey municipal solid waste open dumping site leachates, Environmental Monitoring and Assessment, 185, 9435-9449.

Hazra T. and Goel S. (2009), Solid waste management in Kolkata, India: Practices and challenges, Waste Management, 29, 470-478.

Kale S.S., Kadam A.K. and Kumar S. (2010), Evaluating pollution potential of leachate from landfill site, from the Pune metropolitan city and its impact on shallow basaltic aquifers, Environmental Monitoring and Assessment, 162, 327-346.

Kjeldsen P., Barlaz M.A., Rooker A.P., Baun A., Ledin A. and Christensen T.H. (2002), Present and Long-Term Composition of MSW Landfill Leachate: A Review, Critical Reviews in Environmental Science and Technology, 32, 4, 297-336.

Li J., Wang Y., Xie X. and Su C. (2012), Hierarchical cluster analysis of arsenic and fluoride enrichments in groundwater from the Datong basin, Northern China, Journal of Geochemical Exploration, 118, 77-89.

Li W., Hua T., Zhou Q., Zhang S. and Li F. (2010), Treatment of stabilized landfill leachate by the combined process of coagulation/flocculation and powder activated carbon adsorption, Desalination, 264, 56-62.

Lo I.M.C. (1996), Characteristics and treatment of leachates from domestic landfills, Environment International, 22, 4, 433-442.

Maiti S. K., De S., Hazra T., Debsarkar A. and Dutta A. (2016), Characterization of Leachate and Its Impact on Surface and Groundwater Quality of a Closed Dumpsite-A Case Study at Dhapa, Kolkata, India, Procedia Environmental Sciences, 35, 391-399.

Matejczyk M., Plaza G.A., Nalecz-Jawecki G., Ulfig K. and Markowska-Szczupak A. (2011), Estimation of the environmental risk posed by landfills using chemical, microbiological and ecotoxicological testing of leachates, Chemosphere, 82(7), 1017-1023.

MoEFCC (2016). Municipal solid waste management and handling rules. New Delhi: Ministry of Environment, Forests and Climate Change, Government of India

Mor S., Ravindra K., Dahiya R. and Chandra A. (2006), Leachate characterization and assessment of groundwater pollution near municipal solid waste landfill site, Environmental Monitoring and Assessment, 118, 435-456.

Nagarajan R., Thirumalaisamy S. and Lakshumanan E. (2012), Impact of leachate on groundwater pollution due to nonengineered municipal solid waste landfill sites of erode city, Tamil Nadu, India, Iranian Journal of Environmental Health Science \& Engineering, 9, 35.

Nguyen T.T., Akira K.A., Tong T.N., Nakagawa N., Amaguchi H. and Gilbuena JrR. (2014), Hydrogeochemical characteristics of groundwater from the two main aquifers in the Red River Delta, Vietnam, Journal of Asian Earth Sciences, 93,180-192.

Parameswari K., Mudgal B.V. and Nelliyat P. (2012), Evaluation of groundwater contamination and its impact: an interdisciplinary approach, Environment Development and Sustainability, 14, 725-744.
Piper A.M. (1944), A graphical procedure in the geochemical interpretation of water analysis, Transactions-American Geophyscal Union, 25, 914-928.

Ramesh K. and Elango L. (2012), Groundwater quality and its suitability for domestic and agricultural use in Tondiar river basin, Tamil Nadu, India, Environmental Monitoring and Assessment, 184, 3887-3899.

Sahu P. and Sikdar P.K. (2008), Hydrochemical framework of the aquifer in and around East Kolkata Wetlands, West Bengal, India, Environmental Geology, 55, 823-835.

Siddiqui A., Naseem S. and Jalil T. (2005), Groundwater quality assessment in and around Kalu Khuhar, super highway, Sindh, Pakistan, Journal of Applied Sciences, 5(7), 1260-1265.

United States Environmental Protection Agency (USEPA) (1999) National primary drinking water regulations. http://www.epa.gov/OGWD/hfacts.html. Accessed 17 January 2016

Vasanthavigar M., Srinivasamoorthy K., Vijayaragavan K., Rajiv Ganthi R., Chidambaram S., Anandhan P., Manivannan R. and Vasudevan S. (2010), Application of water quality index for groundwater quality assessment: Thirumanimuttar sub-basin, Tamil Nadu, India, Environmental Monitoring and Assessment, 171, 595-609.

West Bengal Pollution Control Board (WBPCB) (2014) Water quality information system.

http://emis.wbpcb.gov.in/waterquality/showwqprevdata.do. Accessed 11 August 2016

Wilcox L.V. (1948) The quality of water for irrigation use. U.S. Department of Agriculture, Technical Bulletin 962 (40), Washington, DC: U.S. Department of Agriculture

World Health Organization (WHO) (1971) International standards for drinking water. WHO, Geneva

World Health Organization (WHO) (1993) Guidelines for drinking water quality. (2ndedn. vol 1, pp. 188). WHO, Geneva

World Health Organization (WHO) (2002) Guidelines for drinkingwater quality. (2ndedn. pp. 940-949), Health criteria and other supporting information. WHO, Geneva

World Health Organization (WHO) (2004) Guidelines for drinkingwater quality. (3rdedn. vol. 1, pp. 515). WHO Recommendations, Geneva

World Health Organization (WHO) (2011) Guidelines for drinkingwater quality. (4thedn. vol. 1, pp. 472-474), WHO Recommendations, Geneva

Yidana S.M., Banoeng-Yakubo B. and Akabzaa T.M. (2010), Analysis of groundwater quality using multivariate and spatial analyses in the Keta basin, Ghana, Journal of African Earth Sciences, 58, 220-234. 